(C) 1982 ISIJ

\title{
転炉技術を利用した石炭ガス化
}

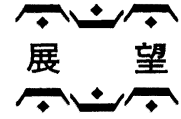

田上豊助*

\section{Coal Gasification Based on the Application of BOF Steel Making Technique}

Toyosuke TANOUE

\section{1. 鉄鋼業における副生ガスの発生量}

鉄鋼一貫製鉄所に拈いては多量の副生ガスを発生して いる。わが国鉄鋼業の湖生ガ久の発生量を全国都市ガ久 供給品，全相発電電力舅（们家用を除く）と比較した結 果を表 112) に示す.

副生ガスの $53 \%$ は嚆炉ガスで， $40 \%$ がコークス炉 ガス，転炉がスが 7\%を占めている。これらの副生ガ 久の合訣昂は $183 \cdot 10^{12} \mathrm{kcal} / \mathrm{y}$ で, 都市ガス供給量の $186 \%$, 発電電力出: (出力) の $38 \%$ にも達している. 鉄 鋼業の剖生:ガスはその一部は共同火力発電所やガス会社 に供給されているが，大部分は製鉄所以で自家用に消費 されている，その主原料は石炭であるが，都市ガスや火 力発電では LNG, LPG や重油を主原料としている. したがつて鉄鋼業界は不炭を原料とするガスの生産や使 用については他業界に比べて厈倒的に大きな実績を有し ている。この基盤に立つて副牛ガスの回収強化ないしは 堌産による们沺系燃料の削減, 副生ガス利用の新分野の 開拓，さらには製鉄技術を忍用した新しいガス化法の開 発など不涔利用払大のための技術開発に力を傾注する気 運が高まつている。

\section{2. 石炭ガス化法の分類, 特徵および問題点}

\section{1 分 類}

石炭ガス化法はガ火化炉の型式によつてつぎの四種に 大別されている。

(1) 洞定床炏iルルギー炉など

(2) 流動林炉 ウインクラー炉など

(3) 㜔流床炉 コッパース・トチェック炉など

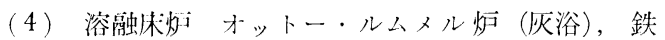
浴灯i

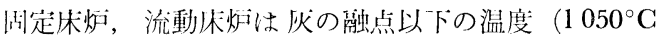
以下）で操業する Dry Ash Type の炉で, ガス化反応 は

熱分解 (乾溜)

水性ガス化度忘 $\left(\mathrm{C}+\mathrm{H}_{2} \mathrm{O} \rightarrow \mathrm{H}_{2}+\mathrm{CO}\right)$
表 1 鋼鋼業の副生ガス発生量，全国都市ガス供給 量, 全国発電電力量（出力，自家用除く）の比較

\begin{tabular}{|c|c|c|c|c|}
\hline 別 & \multicolumn{2}{|c|}{ 生産量 $10^{12} \mathrm{kcal} / \mathrm{y}(\%)$} & \multicolumn{2}{|l|}{ 原料構成(\%) } \\
\hline 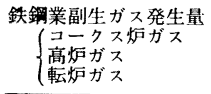 & $\begin{array}{l}183.01 \\
\left\{\begin{array}{l}73.60 \\
96.08 \\
13.33\end{array}\right.\end{array}$ & 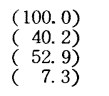 & $\left\{\begin{array}{l}\text { 石炭 } \\
\text { 重油 }\end{array}\right.$ & $\begin{array}{r}95.7 \\
4.3\end{array}$ \\
\hline $\begin{array}{l}\text { 全国都市ガス供給量 } \\
\text { 㨊 購 産 }\end{array}$ & $\left\{\begin{array}{l}100.65 \\
84.31 \\
16.34\end{array}\right.$ & $\begin{array}{l}(100.0) \\
(83.8) \\
(16.2)\end{array}$ & $\left\{\begin{array}{l}\text { 石炭系 } \\
\text { 石油系 } \\
\text { 天然力゙ } \\
\text { その系 }\end{array}\right.$ & $\begin{array}{r}13.3 \\
35.5 \\
51.2 \\
0.1\end{array}$ \\
\hline $\begin{array}{l}\text { 全国発電電力量(出力) } \\
\text { 永 } \\
\text { 炎 } \\
\text { 原子力 }\end{array}$ & $\left\{\begin{array}{r}442.08 \\
73.22 \\
298.33 \\
70.53\end{array}\right.$ & $\begin{array}{l}(100.0) \\
(16.6) \\
(67.5) \\
(15.9)\end{array}$ & $\begin{array}{l}\text { 火力発電原料構成 } \\
\left\{\begin{array}{l}\text { 石岩油系 } \\
\text { 天然ガス系 }\end{array}\right.\end{array}$ & $\begin{array}{l}11.9^{11} \\
65.6 \\
22.5\end{array}$ \\
\hline
\end{tabular}

注 1 ) 発電用炭 7.65、コーク炬ガス・高炬ガス 4.21

の比率が高い。したがつて粗がスには $\mathrm{CH}_{4}, \mathrm{H}_{2}$ が高 く, タールやアンモニヤの発生が多い.

噴流床炉，溶融床炉は灰の融点以上の 温度 $\left(1450^{\circ} \mathrm{C}\right.$ 以上) で操業する Molten Ash Type の炉で

部分酸化反応 $\left(\mathrm{C}+1 / 2 \mathrm{O}_{2} \rightarrow \mathrm{CO}\right)$

の比率が高く, $\mathrm{CO}$ と $\mathrm{H}_{2}$ の比が約 2:1 のガスを生成 する. タールや炭化水素の含有が少なく, 化学合成に適 している.

\section{$2 \cdot 2$ 固定床ガス化炉}

昭和 20 年代までガスだき平炉の燃料用に多数稼動し ていたガス発生炉もこれに属する。シャフト炉の上部か ら粒・塊炭を装入し，下部から吸き込んだ空気または $\mathrm{O}_{2}$ とスチームが下降する石炭の間隙を向流式に上昇し ながら反応する。

$\mathrm{O}_{2}$ の使用々高王化により能力を高めたものにルルギ 一炉3)がある。 その構造を図 1 に示す. $30 \mathrm{~atm}$ 程度の高 圧炉で内部に攪挥翼を持つている。

代表的なガス組成\%；

$$
\begin{array}{ccccc}
\mathrm{CO} & \mathrm{H}_{2} & \mathrm{CH}_{4}+\mathrm{C}_{\mathrm{n}} \mathrm{H}_{\mathrm{m}} & \mathrm{CO}_{2} & \mathrm{~N}_{2} \\
19 & 39 & 11 & 30 & 1
\end{array}
$$

南アフリカ連邦の SASOL を始め世界各地に 100 基 以上の実績を持つている.

この炬の欠点としては

炤和 57 年 8 月 20 日受付 (Received Aug. 20，1982) (依頼展望)

* 住友食属工籍(怢) 大渡本社: 工博 (Osaka, Sumitomo Metal Industries, Ltd., 5-15 Kitahama Higashi-ku Osaka 541) 


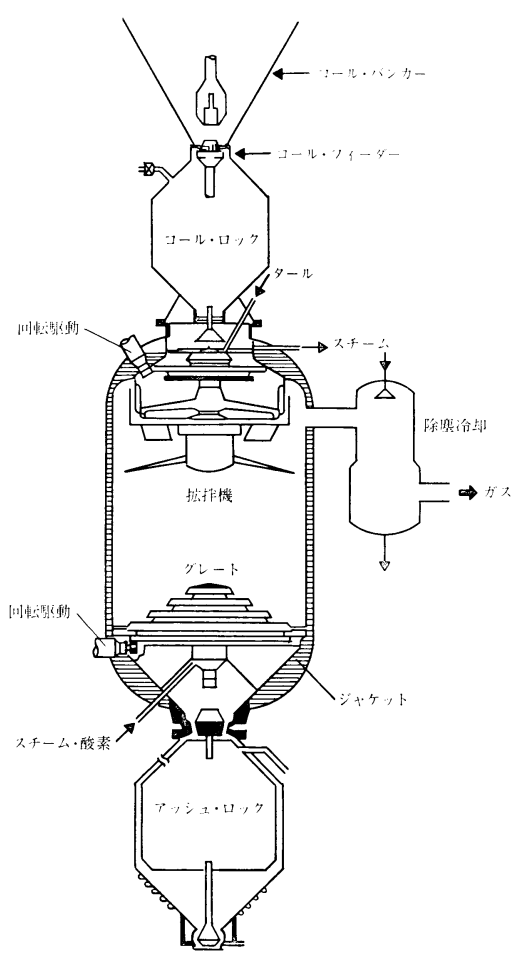

図1ルルギー・ガス化好

(1) 粉炭の使用が不能

（2）タール，炭化水素，アンモ二ヤなど副生品の発 生が多い。ガスの不純物も多く精製にコストが かかる.

（3）スチームの反応効率が低い.

（4）炉内の通気性確保のため炉径に制限があり，大 型化に限界がある。

(5) 操業の安定性

などが指摘されている.

この炉の改良型として灰の融点以上の高温度で操業す るルルギー・スラッギング炉4) の開発が British Gas Corporation と共同で進められている. 従来のルルギー 炬に比べて生産性が大きく, 副生品の発生が少ない，粉 炭の利用も可能で, CO の高い中カロリーガスを産出す る.この炉は下部に灰の軟化溶融帯を持つことになるの で, 通気性コントロールがより困難になると思われる が，今後の進展が注目される.

\section{3 流動床ガス化炉}

粉炭を空気または $\mathrm{O}_{2}$ とスチームで流動ガス化する力 法で, 灰が溶融しない $1100^{\circ} \mathrm{G}$ 以下の温度で操業が行 われる。

古くから有名なウインクラー炉5) は 38 基の稼動実績 を持つている．流動床炉ではガス化温度が高いほど $\mathrm{CO}, \mathrm{H}_{2}$ の発生が多く, $\mathrm{CO}_{2}$ や未反応スチーム, 未反
忍炭塵の発生が少なくなる.

HTW(High Temperature Winkler)6) の䦌発が Rheinische Braun Kohle によつて進められている。最 高 $10 \mathrm{~atm}, 900 \sim 1100^{\circ} \mathrm{C}$ でガ火化を行う。

代表的なガス組成\%；

$$
\begin{array}{lllll}
\mathrm{CO} & \mathrm{H}_{2} & \mathrm{CH}_{4} & \mathrm{CO}_{2} & \mathrm{H}_{2} \mathrm{O}
\end{array}
$$$$
\begin{array}{lllll}
35 & 30 & 3 & 17 & 15
\end{array}
$$

流動床炉は多種多数のものが主として粗目で閁発に着 手されたが，温度が高いとクリンカー・トラブルが発生 するし，温度が低いとガ火化効摔がトがるという操業条 件の困難性から大部分のものは中止または進行停滞の状 況にある. その中にあつて現在米国では W.H 法7 (Westinghouse Electric Corporation), U ガ 久法8) (Institute of Gas Technology), H本では石岑技研法, 日立ハイブリッド法9)の開発が進められている。

流動床ガス化法の問題点としては

（1）エネルギー転換効率が低い.

粗ガスの $\mathrm{CO}_{2}$ が高い. 未然炭ダ火卜や排出炏 への未反応炭の混入が多く不扊利用济が低い。

(2) タールを発生する.

などが指摘されている.

\section{4 噴流床カスス化炉}

部分酸化を主要反忘とするバーナー燃接式のガ火化炉 である。商業炉としてはュッバース・トチェック炉10が あり，60 基以上の稼動䇛績がある。わが非でも数基稼 動していた報告がある。四2 に亦すような2 j们または 4 方向からの対向バーナーを採用した常北灿である.

代表的なガス組成\%；

$\begin{array}{llll}\mathrm{CO} & \mathrm{H}_{2} & \mathrm{CO}_{2}\end{array}$

$\begin{array}{lll}60 & 30 & 10\end{array}$

$\mathrm{CH}_{4}, \mathrm{C}_{\mathrm{n}} \mathrm{H}_{\mathrm{m}}$, タールはきわわて低い.

この炉の問題点は

(1) 生産性が低い.

(2) $\mathrm{CO}_{2}$ がやや高い.

（3）粗ガスが常压であるため，化器命成用としては

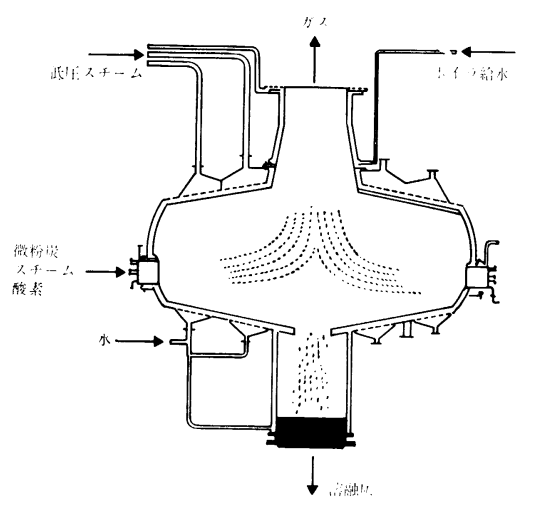

闵 2 コッパース・トチェック・ガス化䏓 
ル絎コストがかかる。

ことなどである。こ水らの久然を改良するため，開発中 のテキサコ炉，シェル・コッパース炉などはいずれも

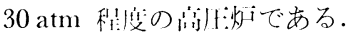

テキ+コ为11)では粉贸を水久ラリーにして供給してい るので，文心温度が過早の水によつて抑制され，そのた d $\mathrm{CO}_{2}$ の発生が多い. 化命水分や灰分の高い石岑は使 用しにくい.

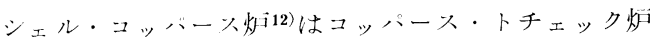
を问訛したもので，高归に伴う $\mathrm{CO}_{2}$ の増加を抑え るたる $1800^{\circ} \mathrm{C}$ 以に:の吕滥を採用している，粗ガスの $\mathrm{CO}_{2}$ は $2 \%$ 以トで非常に低い. 炉ラインニングの保持 のたひ刚壁近傍に水冷チューブ・ウォールを採用してい る.

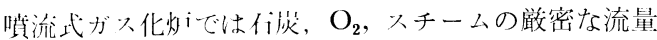
制御，未燃淡の発㤝を防止するための特殊な燃焼方法 (刘问バーナーなど)，ならびにライニングの保持とその 監視法が棵题であると苦われている。

\section{5 溶融床ガス化炉}

浴融した灭浴や鉄浴の主而李たは浴中に石炭， $\mathrm{O}_{2}$ ， ス チームを吹き付け， $1500^{\circ} \mathrm{C}$ 付近の温度で反忘させてガ 火化与る。

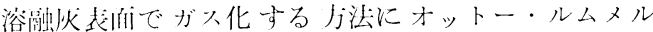

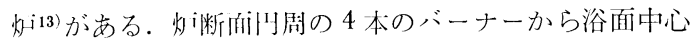
周りに施川流を尗るよらに石荻， $\mathrm{O}_{2}$ ，大チームを吹き 付ける・1少ガ火流も旋间流となつて反応效率を高める。 粗ガ火紌成は $\mathrm{CO}, \mathrm{H}_{2}$ 主:体のもので, $\mathrm{CO}_{2}$ は約 $10 \%$ であつた。 オットー・ルムメル炉は常压炉であつたが， 竖菜化に市らず，晛在はザールベルグ・オットー炉14) と して $30 \mathrm{~atm}$ の高壮炉の開発が進められている. 反缊 度は $1600^{\circ} \mathrm{C} \sim 2200^{\circ} \mathrm{C}$ と言われ，炉の内壁にはヒレ付 管のチューブ・ウォールが採用されている．扊浴ガス化 炉の炎浴使用の意孚については必ずしも明確でないよう に思わ机。令後，シェル・コッパース炉との比較によ つて明らかにされるであるら。

鉄浴を使用するものに AT 法15)，新明和法，住友金 属法16)などがある。これについては以下に詳述する。

\section{3. 鉄浴ガス化法の歴史}

\subsection{AT 法}

1970 伴比から Applied Technology Corporation (米国) が初めて鉄浴が久化炉の実験に 着手している. 図 3 に亦与ように，们荻供給ランスと石灰石・酸素供給 ランスの 2 本のラン火を鉄浴内に浸漬してガス化を行わ せるお式である。挪結果によれば石炭， $\mathrm{O}_{2}$ ともに鉄

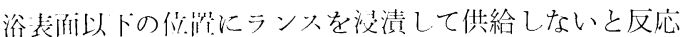

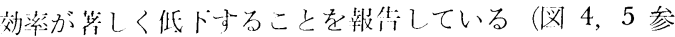
照).

この洨滇供給条件で生成する粗ガスは CO $63.5 \%$,

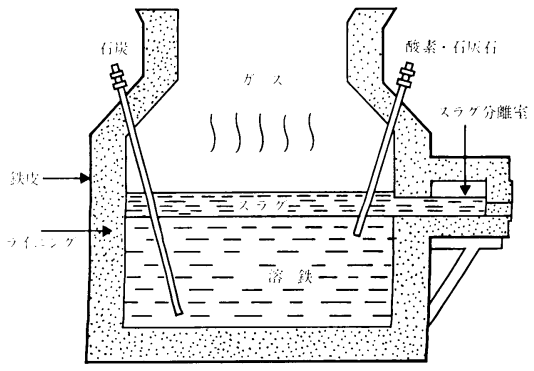

図 3 AT 法ガス化炉

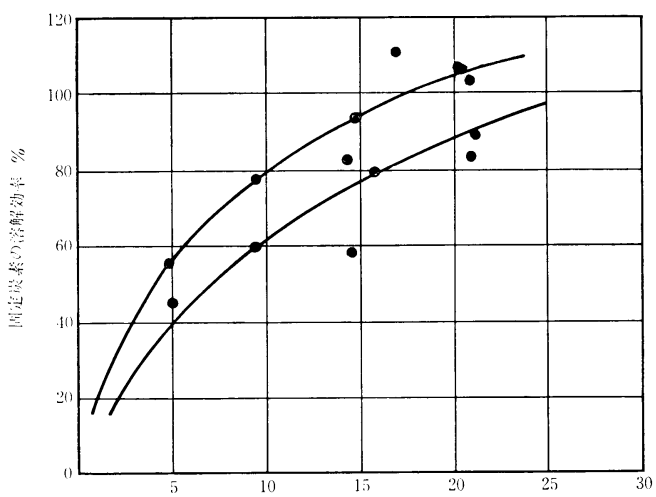

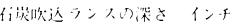

図 4 固定炭素の溶解効率

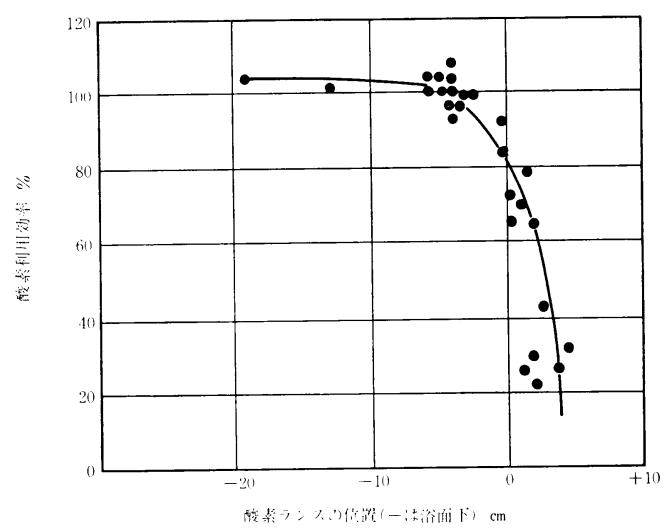

図 5 酸素の利用効率

$\mathrm{H}_{2} 36.0 \%, \mathrm{CO}_{2}$ と $\mathrm{S}$ が極めて低い良好な組成を持つこ とを確認しているが，鉄浴 $2.7 \mathrm{t}$ までの実験段階で開発 を中止している。

\section{2 新明和法}

1974 年から 1977 年にかけて, 新明和工業(株)がサン シャイン計画本部の依託により図 6 に示す 2 室式ガス化 炉の開発を進めた。眓の右室で石炭をスチームと反応さ せて $\mathrm{CO}, \mathrm{H}_{2}$ を製造する。この水性ガス化反応の吸熱 による鉄浴温度の降下を補償するため，電磁ポンプで溶 


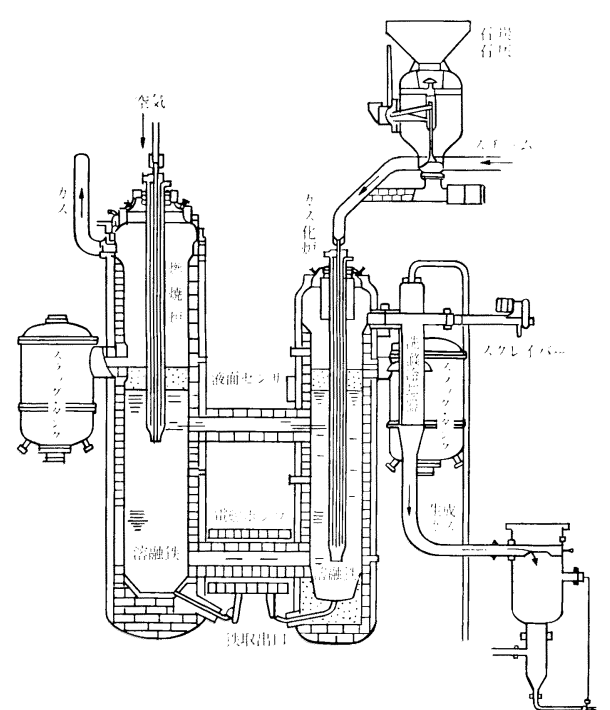

図 6 新明和法の二塔式ガス化炒

鉄を左室に循環移動させ，左室で空気を吸き込んで鉄浴 中の溶解炭素を燃焼させて溶鉄の温度を上げる，電磁ポ ンプによる循環実験は溶融亚鉛を使用して垁施した。浸 漬ランスの溶損が問題となり, 解決のため数 10 種類の 耐火物のテストが行われた. 本法も要素試験の段階で開 発が中止された。

\section{3 スウェーデン王立工科大学における研究}

スウェーデン王立工科大学では 1975 年北から鉄浴や 銅浴を使用して浸漬ランス方式のガス化実験を尖施し た.

さらにその後, 鉄浴炉の炉底から不炭， $\mathrm{O}_{2}$ を吹き込 みガス化反応の余剩熱で㕍鉄を溶解するプロセス，すな わち石炭ガス化と溶銑製造とを結合したプロセスの実験 を行つた. このプロセスは IEA の国際共同研究テーマ に採択されてわが国と共同開発を進めることとなり，新 日本製鉄 (株)，日本鋼管 (株)，(株) 神户製鋼所の三社が 協力してフィージビリ・スタディを実施中である.

\subsection{Humboldt 法}

KHD Humboldt Wedag AG (西独) ${ }^{17)}$ は 1978 仨に Applied Technology Corporation の特許権を買い取り, その後スウェーデンの MEFOS の $6 \mathrm{t}$ 試験転炉を借用 して底吹き法によるガス化実験を実施した，Q-BOP に よく似た底吹き羽口から石炭, $\mathrm{O}_{2}$, 石岑を供給する方法 である. 生成ガスは $\mathrm{CO}, \mathrm{H}_{2}$ に富多 $\mathrm{S}$ が低く, $\mathrm{AT}$ 法 によく似たガス組成が得られたことを発表している.今 後さらに石炭 $10 \mathrm{t} / \mathrm{h}$, ガス発生量 $20000 \mathrm{Nm}^{3} / \mathrm{h}$, 操業 压 $10 \mathrm{~atm}$ の大型試験プラントを建設すべく案画を進め ている (図 7 参照).

\section{5 住友金属法}

1978 年, 住友金属工業 (株) は上欣き転炉技術を心用

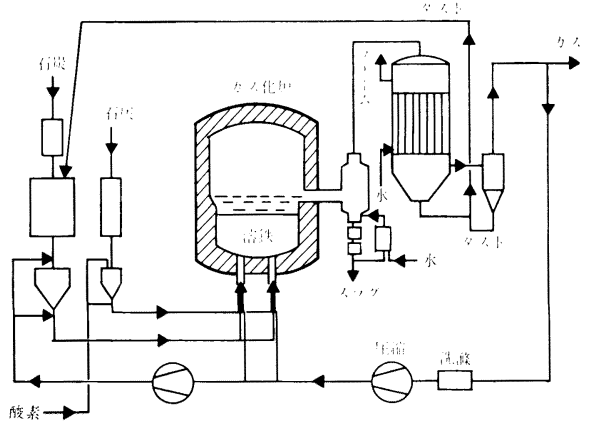

図 7 KHD 不谈ガス化泣

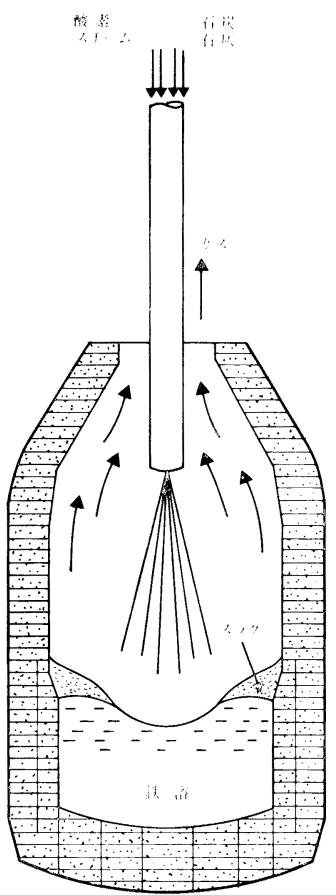

図 8 上吹きガス化泣（住友金闻）

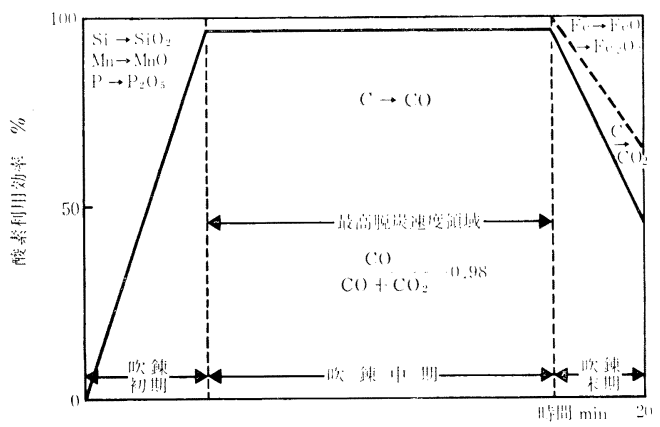

図 9 転灯吹錸過程の陵化火芯 
した鉄浴ガ火化江の閁発に着于した。住友金属法は非浸

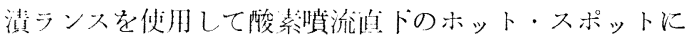
们焂や人チームを源加与るとこうに特徵がある。先にも 述べたよらに従米一般に非浚漬ランスによる上吹き法で は効涪のよいガ入化は困難であると理解され，浸漬ラン 人泣や底收き法による開発が行われてきた，住友金属で

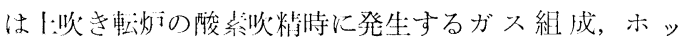
卜.人ボットの滥度や浴速動, 出鋼加炭時に打沙炭素 の溶解性などに隊与る製鋼操紧の知見から非浸漬ランス による1:收き江汇よつても发好なガス組成を得ることが 川能であるらとのア胃に到達した。

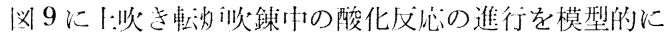

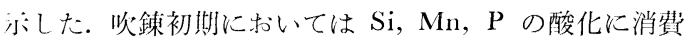
される $\mathrm{O}_{2}$ が多く，脱览に消监される $\mathrm{O}_{2}$ の制合は小さ い.川期になると $\mathrm{O}_{2}$ の汪とんど全部が脱岑に消費され る。この侍期の発价がスは 98\% 以上が CO であり， 脱谈酸系效泫は 100\% に近い。未期になると $\mathrm{Fe}$ の酸 化や $\mathrm{CO}_{2}$ の牛成比消䝨される $\mathrm{O}_{2}$ が增加し $\mathrm{CO}$ の発 牛は減少する。住友金属ではこの転炉吹鍊中の発生ガス

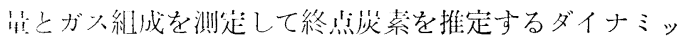

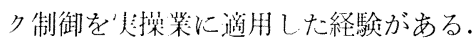

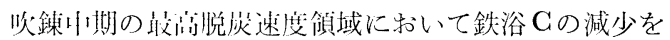
補足するだけの们苂を添加して鉄浴に溶解させ，鉄浴 $\mathrm{C}$ を一定值（約 $0.6 \%$ ）以上保持することができれば石 苂ガ火化が成立与るわけである. 石荻の溶解が道れると
転炉收錬末期のように鉄浴 $\mathrm{C}$ が低下して $\mathrm{Fe}$ の酸化と $\mathrm{CO}_{2}$ の增加が起こりガス化効率が低下する。 したがつ て酸素供給速度は石岑の溶解速度で規制されることにな る。そのため石炭は温度がもつとも高く浴の㩭拌がもつ とも大きいホットスポット付近（浴凹み）に添加卞るこ とが必要である.

従来非浸漬ランスによる上吹き法では効率のよいガス 化が困難視されていた主な理由は小さな実験規模の試験

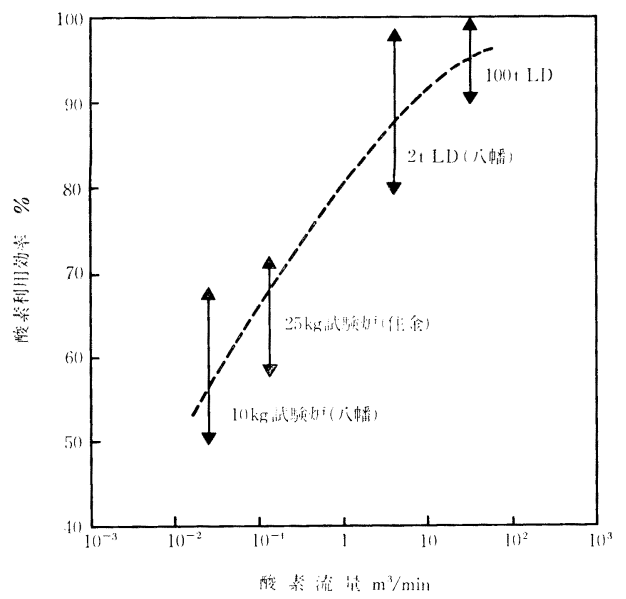

汹 $10 \mathrm{LD}$ 転炉の大きさと酸素利用効率（新日鉄・ 瀨川ら)

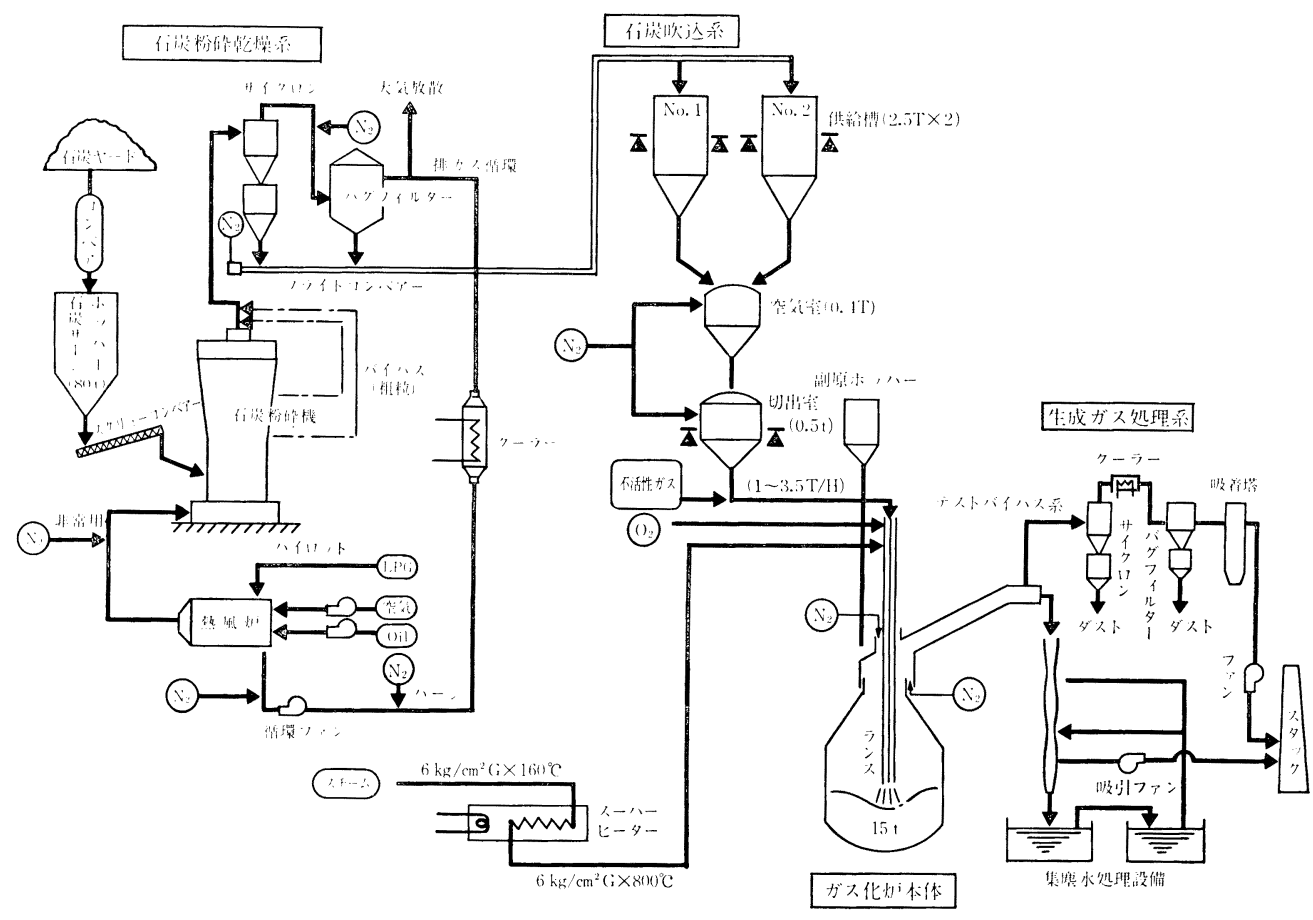

脑11 ガス化試験設備フロー 
絬果のスケール・アップ效果の評価ミスであつたと思わ れる。図10 亿示すように上吹き転灯の脱炭は灯容最が 小さくなると酸素利用效率が低下し $\mathrm{CO}_{2}$ の発生が增大 することはよく認識されていることである。浴樑さの小 さい小型哣では酸素噴流の浴而に拈ける動压を大きく採 ることができず，一部の $\mathrm{O}_{2}$ は浴血化接触することなく 生成がスの $\mathrm{CO}$ と反応して $\mathrm{CO}_{2}$ を增加する。李た浴 の㨨抖が弱いため石炭の溶解速度が小さくなる。

住:友金属では 1978 年 1 月, 中央技術研究所の $60 \mathrm{~kg}$

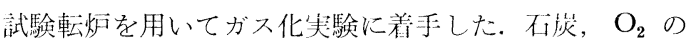
供給方法, 石炭粒度の選択などについて 30 ヒート以上 のテストを行い操業条件適正化の方向を把握することが できた．しかしこの小型炉では予想されたように $\mathrm{CO}_{2}$ の低いがスを得ることができなかつたので，引き続き $2 \mathrm{t}$ 炉による実験が央施された。 $2 \mathrm{t}$ 炉用に特別飞設計製 作した超ハードブロー・ランスを用いた試験では, 比較 のため寒施した底吹き法と同等の $\mathrm{CO}_{2} 3 \%$ 以下の良好 なガスを得ることができた。これとよつてがス組成の目

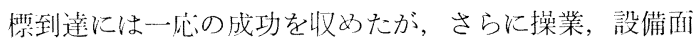

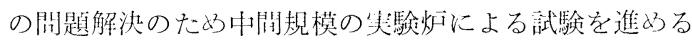
こととなつた.

1979 年: 4 月，これまでの基礎战験のデータをもとに，

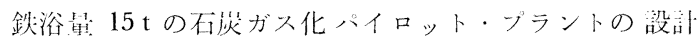
が始亦り，1980 年 2 月鹿島製鉄所以に建没を完了し， 5

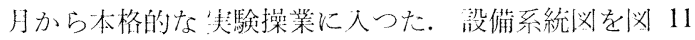
に示す。

尖験は最初,

(1) $\mathrm{CO}_{2}$ の低い $\mathrm{H}_{2}$ の高いガ入を待るための $\mathrm{O}_{2}$, 久チームの反応效湾の向上.

(2) $\mathrm{H}_{2} \mathrm{~S}, \mathrm{COS}$ の低い粗ガ火を得るための炣队脱 硫滀の问上

表 2 铁浴上欦きガス化法实験絬果の一例

\begin{tabular}{|c|c|c|c|c|}
\hline 炭 & $\begin{array}{l}\mathrm{FC} \\
\mathrm{VM} \\
\text { 灰分 } \\
\text { 水分 }\end{array}$ & $\begin{array}{r}55.4 \% \\
34.4 \% \\
8.0 \% \\
2.2 \%\end{array}$ & $\begin{array}{l}\mathrm{C} \\
\mathrm{H} \\
\mathrm{O} \\
\mathrm{N} \\
\mathrm{S}\end{array}$ & $\begin{array}{l}84.3 \% \\
5.2 \% \\
7.9 \% \\
1.8 \% \\
0.8 \%\end{array}$ \\
\hline $\begin{array}{l}\text { 操 } \\
\text { 業 } \\
\text { 諸 } \\
\text { 元 }\end{array}$ & \multicolumn{2}{|c|}{$\begin{array}{l}\text { 石 炭 } \\
\text { 酸 素 } \\
\text { スチー公 } \\
\text { キャリヤーガス (Ar) } \\
\text { 生石灰 } \\
\text { ホタル石 }\end{array}$} & \multicolumn{2}{|c|}{$\begin{array}{c}2.5 \mathrm{t} / \mathrm{h} \\
575 \mathrm{Nm}^{3} / \mathrm{t} \text { 石崖 } \\
>150 \mathrm{~kg} / \mathrm{t} \text { 石炭 } \\
50 \mathrm{Nm}^{3} / \mathrm{t} \text { 石崖 } \\
80 \mathrm{~kg} / \mathrm{t} \text { 石岑 } \\
10 \mathrm{~kg} / \mathrm{t} \text { 石炭 }\end{array}$} \\
\hline $\begin{array}{l}\text { 生 } \\
\text { 成 } \\
\text { ガ } \\
\text { ス }\end{array}$ & \multicolumn{2}{|c|}{ 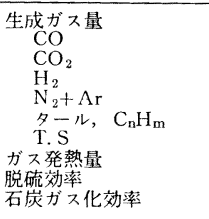 } & & $\begin{array}{l}0 \mathrm{Nm}^{3} / \mathrm{t} \text { 石炭 } \\
64 \% \\
<3 \% \\
33 \% \\
64 \% \\
\mathrm{r} \\
00 \mathrm{ppm} \\
\mathrm{cal} / \mathrm{Nm}^{3} \\
90 \% \\
98 \%\end{array}$ \\
\hline $\begin{array}{l}\text { 夕 } \\
x \\
1\end{array}$ & \multicolumn{2}{|c|}{$\begin{array}{l}\text { 発 生 量 } \\
\text { T. C } \\
\text { T. Fe } \\
\text { T.S }\end{array}$} & & $\begin{array}{l}\mathrm{g} / \mathrm{Nm}^{3} \\
13 \% \\
60 \% \\
5 \%\end{array}$ \\
\hline
\end{tabular}

（3） スピッティングおよびッロッビングの低減

(4) 父卜発生: 督の減少

(5) 軵火物消费歯の低娍

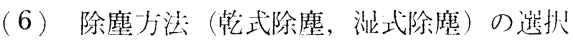
などの解明を主目的に進邓られたが，乥の後，

（7）炉ロシール法の改淿

(8) 連紹排野泣の確立

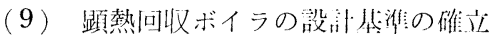

(10) 固体鉄原料からの鉄浴造成江の'完成 などの問題が加わり，この中すでと大激分の項山につい、 ては成功裡に試験を終了している。をして攱後に

(11) 長時間連続操業の確諰

のための試験が予定されている。な沶 $15 \mathrm{t}$ 炉の試験に

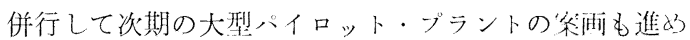
られている。実験絬果の一部を犮 2 に心した。

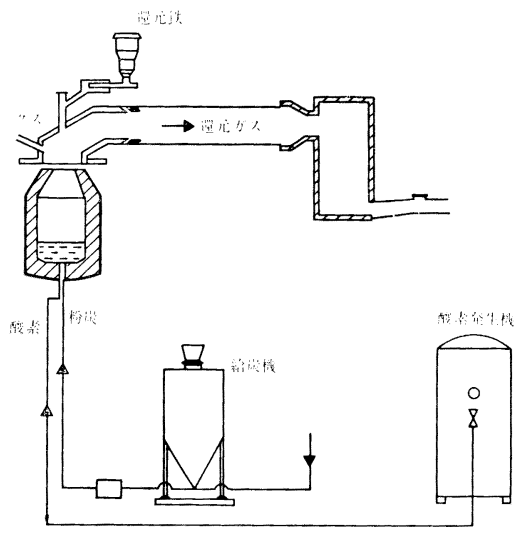

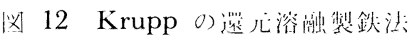

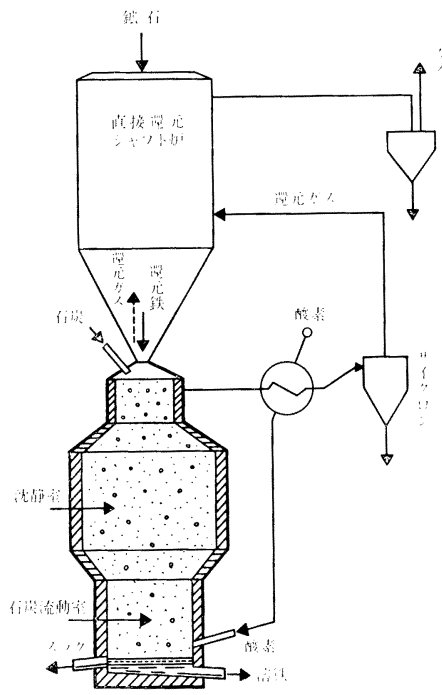

图 $13 \mathrm{KR}$ 嗃元溶融製鉄泣（Korf Stahle AG) 


\section{6 製鉄法との合併法, その他}

鉄浴ガ火化㭁で製适したガ入を凹接製鉄シャフト炕に

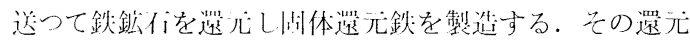
鉄を鉄浴ガ入化炋装入して溶解し溶銑を製造する。こ

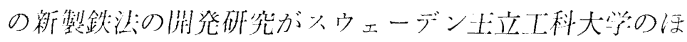
か, Krupp Forschung Institute ${ }^{18)} \ngtr$ Korf Stahle AG19)でも行わ水ている(汹12, 瑊13 参照). また

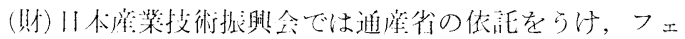

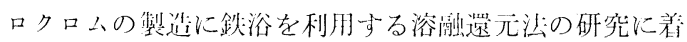
手しててる。

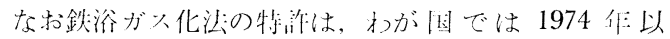
後, 新明和丁:策(株)，主排造船(株)，新日本製鉄(株)を はじめ多数出愿公售されている。また鉄浴ガス化の基礎 研究が東宗大“圷学部20)で進められている。

\section{4. 鉄浴ガス化炉における反応}

\section{$4 \cdot 1$ 主要なガス化反応}

鉄浴炉におけるガ火化皮伈の概型を表 3 に示す。他の ガス化法における文扎と異なる点は石炭中の $\mathrm{C}, \mathrm{S}$ の大 淿分が・11浴鉄けに溶解し，溶鉄に溶解した C, S が $\mathrm{O}_{2}$ や久ラグと皮仙するところに特徵がある。石炭は分

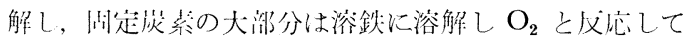

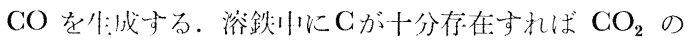
生成は抑制される。隹と $\mathrm{O}_{2}$ との反他だけでは鉄浴滥 度がは多尗るので, $1500^{\circ} \mathrm{C}$ 付近の一定盓度に保持する ためにンチームの添加を行い，水性ガ火皮志の吸熱によ

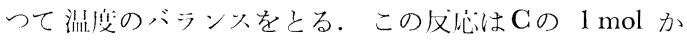
ら $2 \mathrm{~mol}$ のガ火を生成するのでコス卜上有利な反忍で あり，效果们に行うには久チームを鉄浴に十分に接触さ せるように供給することが必装である。

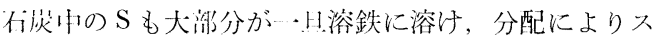
ラグに移行する。分配比はスラグ塩基度に依存する。

\section{2 底吹き法と上吹き法との反応の相違点}

$\mathrm{O}_{2}$ を炉成から供給与る底吹法では $\mathrm{O}_{2}$ の大部分は直 按漼鉄と反心正る。これに対して上吹法では酸素噴流が

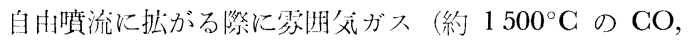
$\mathrm{H}_{2}$ ）を卷き込む，然き込まれた $\mathrm{CO}, \mathrm{H}_{2}$ は $\mathrm{O}_{2}$ と反心 して $\mathrm{CO}_{2}, \mathrm{H}_{2} \mathrm{O}(\mathrm{g})$ となり, さらに鉄浴の $\mathrm{C}$ と反忘し て $\mathrm{CO}, \mathrm{H}_{2}$ に将牛される。浴上空間での石炭の燃焼は
水分の蒸癹，掉癹分の分解など吸熱を伴らため一蔀しか 起らないであるら。

ソフトブローになると貲流ガスの一部は浴而に接触也 ずに炉小に问からため $\mathrm{CO}_{2}, \mathrm{H}_{2} \mathrm{O}(\mathrm{g})$ の含有が高くなり，

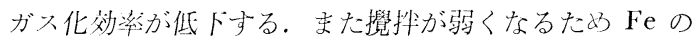
訟化が增加してスラグの $\mathrm{FeO}$ が简くなる。熱的にはン

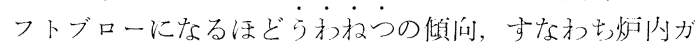
スやスラグの湭度が鉄浴よりも宲くなる傾问を增す。 かし大型炉になるとこれらのソフトブローの影響の度全 いは小さくなる。こ机らの現象は LD 転炉の反伈に酔 似しているとみることができよう。

\section{5. 鉄浴利用の意義}

(1) $\mathrm{CO}_{2}$ および未燃崖塵の発生防止

石岑の大部分を一日，高溫の鉄浴中に溶解させ，溶解 した原子状岑素を $\mathrm{O}_{2}$ と反仙させるので反応が速く, 鉄

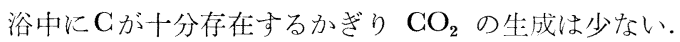

般の噴流式ガス化炉では微粉炭を直接反忍さ也る が，微粉岑には粒子ごとに寸法美があるため紐䊑は $\mathrm{CO}_{2}$ 䒠で然焼しやすく，粗粓は中心部が末燃のまま淡 塵として炉外に搬出され， $\mathrm{CO}_{2}$ や未燃菼塵の発生が避 けにくい。

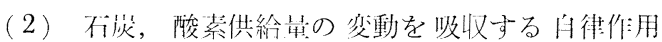

不竾， $\mathrm{O}_{2}$ ，火チームをガ火化に必琶な化学早比で遇続 的に供給することは，微視的には困難な技術（特に不岑 の供給）であるが，鉄浴が存在すれれば，酸素過剩時には 過剩酸素は鉄浴中苂素を消整して $\mathrm{CO}$ を発生し， $\mathrm{CO}_{2}$ の生成を防非する。一j，石苂過剩時には鉄浴が吸荻し て未燃炭素の逸出を防ぐ.このようにして鉄浴は石扊, 酸素供給舁の変動を吸収する目律作用を持つており，ガ スのカロリー変動を少なくする.

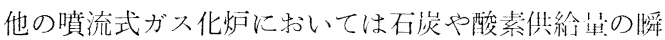
時的変動がそのまま $\mathrm{CO}_{2}$ や末燃恺塵の増加をきたすこ とになる。

(3) 不菼中硫黄の炉内脱硫

石炭中の S の大部分は一旦, 鉄浴に溶解し, ついでス ラグに移行し，スラグと共に炉外に排出される。粗ガス

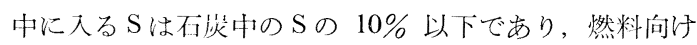
の場合には粗ガスの水洗のみで十分で，特别な脱硫装倠。

表 3 鉄浴不炭ガス化主父志

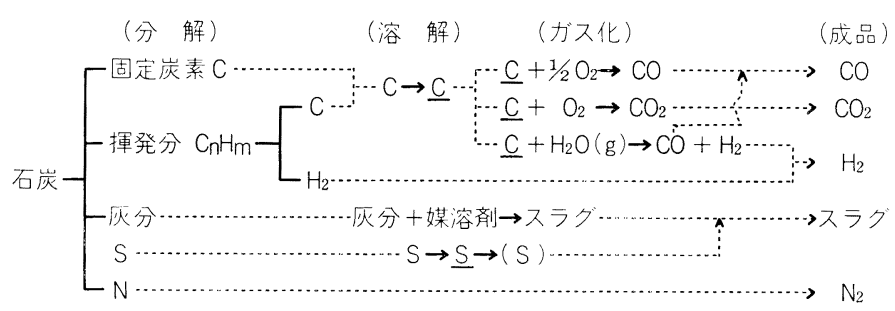


を必要としない.

他のガス化炉の場合には石炭中の S の大部分が粗ガス に含まれて炉外に運ばれるので, 後続の脱硫工程が必要 である。

\section{6. 鉄浴石炭ガス化法の特徴}

(1) 良質ガスの生成

1) $\mathrm{CO}, \mathrm{H}_{2}$ の含有量高く, $\mathrm{CO}_{2}$ が少ない. ……化 学工業用, 還元ガス用にも適用可.

2) $2500 \sim 2700 \mathrm{kcal} / \mathrm{Nm}^{3}$ の中カロリーガスが得ら れる。......燃焼する場合, 空気比小で火焰温度は 高い(約 $2000^{\circ} \mathrm{C}$ ).

3) タール, 分解油, $\mathrm{CH}_{4}, \mathrm{C}_{\mathrm{n}} \mathrm{H}_{\mathrm{m}}$ が僅少. $\cdots \cdots$ ガス 精製設備が簡単.

4) Fuel $\mathrm{SO}_{\mathrm{x}}$, Fuel $\mathrm{NO}_{\mathrm{x}}$ の含有量が少ない.......公 害対策設備が簡略.

（2）使用する石炭の種類に制約が少ない。…圧 分, 固有水分は考慮必要.

（3）ガス化炉の構造が簡単で大型化が容易.

（4）操業が容易. ……LD 転炉の操業技術および計 測制御技術の適用。

などの特徵を有しており，笑用化が可能となれば良質の ガスを比較的安価に製造できると考えられる.

一方，本方式は然料ガスや還元ガス用には適している が常压炉であるために压力を必要とする合成がスや化学 工業原料用のガスとしてはト工程で昇压が必要となる。

\section{7. 結言}

鉄浴ガス化法の基礎研究が開始されたのは 1970 年に 入つてからのことであり, LD 転炉の商業炉の出現が 1952 年であることを考えると, 鉄浴ガス化法はまだ歴 史が浅く, 従来, 浸漬ランス法や底欣き法による垁験が 行われたにすぎない。

住友金属工業(株)では LD 転炉の技術を基盤に，非 浸漬ランス上吹き法によるガス化法の開発に着手した。 良質なガス組成を確認した後, $15 \mathrm{t}$ 鉄浴炉による操業条 件の解明 ·改善を進め, 現在実用化確認のための長時間 操業試験を進めている.

転炉の操業が短時間のバッチ式であるに対し，ガス化 炉では善時間連続操業が必要とされるため, 耐火物をは じめ炉設備にはよりシビアーな耐久性が要求される。近 作進歩した製鋼用耐火物の材質ならびに使用技術を最大 限に活用すると共に，長期操業の実績深い高炉の側壁や 炉底の冷却技術をも採り入れて改善を計り, 鉄浴ガス化 法の完成に努めている.

\section{交献}

1) コ一クス炉，高㭁，転炉作紧湖澘表（昭和 55 年 年計）［日本鉄鋼連盟］

2) 総合エネルギー統計，炤和 56 们度版[资源エネ ルギー庁]

3 ) P. F. H. Rudolph, $C$. Hafhe, and $P . K$. Herbert: Conference of Synthetic Fuels, San Francisco, Oct. 1980

4 ) R. B. Sharman, $J . A$. Lacey, and $J . E$. ScotT: 8th Annual International Conference of Coal Gasification, Liquefaction and Conversion to Electricity, Pittsburg, U. S. A., Aug. 1981

5 ) E. J. Ferretti, K. C. Baczewski, and $A . C$. Mengon: Energy Communications, 5 (1975), p. 433

6 ) $W$. Adlhoch and $K$. A. Theis: Conference of Synthetic Fuels, San Francisco, Oct. 1980

7 ) J. D. Holmgren, C. E. Seglem, L. $A$. Salvador, and $M$. W. Dyos: Conference of Synthetic Fuels, San Francisco

8 ) J. G. Patel and J.W. Loding: Conference of Synthetic Fuels, San Francisco, Oct. 1980

9 ) 平户瑞穂, 小梁敬堯, 宫寺 博: 化兴工学, 41 (1977)，9， p. 39

10) J. E. Franzen and $E . K$. Goeke: ILAFA Congress on Coal in the Steel Industry of Laten American Iron and Steel Institute, Mexico City, July 1976

11) W. R. Siegart: Conference of Synthetic Fuels, San Francisco, Oct. 1980

12) M. J. Van der Burgt and J. Waller: 8 th Annual International Conference of Coal Gasification, Liquefaction and Conversion to Electricity, Pittsburgh, U. S. A., Aug. 1981

13) G. J. Manthos and E. E. Ellington: Economics of Gasification of Solid Fuels in the Rummel/Otto Gasifier, Jan. 1977, Prepared for ERDA

14) $G$. Füssman and $M$. Rassbagh: Conference of Synthetic Fuels, San Francisco, Oct. 1980

15) Applied Technology Corp.: Coal Age, Jan. 1972, p. 59

16) $T$. Tanoue, $S$. Okamura, $M$. Sueyasu, $M$. Fukuda, $T$. Matsuo, and $K$. Okane: 8 th Energy Technology Conference and Exposition, Washington, March 1981

17) P. Paschen, R. Pfeifer, and H. D. Waldhecker: 8th Energy Technology Conference and Exposition, Washington, March 1981

18) $J$. Hartwig, D. Neuschütz, and Radke: Stahl u. Eisen, 100 (1980) 10, p. 535

19) DOS 28433034 Oct. 1978: Stahl u. Eisen, 100 (1980) 20, p. 1207

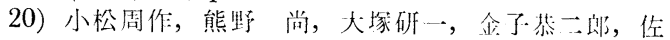
野信雄，相馬㳙和：鉄と鍋，67 (1981)，S667 